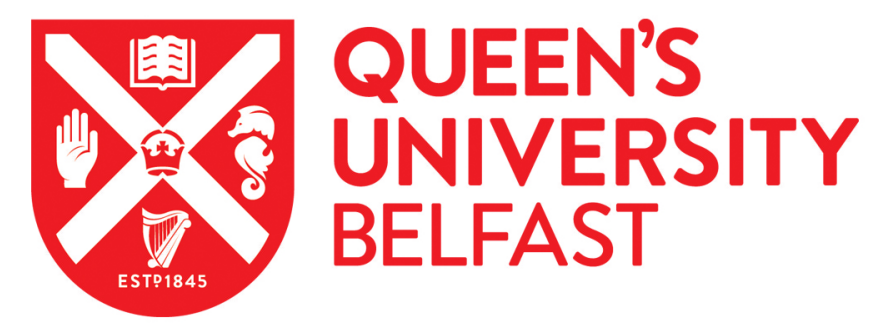

\title{
Developing an integrated hydrograph separation and lumped modelling approach to quantifying hydrological pathways in Irish river catchments
}

O'Brien, R., Misstear, B. D., Gill, L. W., Deakin, J. L., \& Flynn, R. (2013). Developing an integrated hydrograph separation and lumped modelling approach to quantifying hydrological pathways in Irish river catchments. Journal of Hydrology, 486, 259-270. https://doi.org/10.1016/j.jhydrol.2013.01.034

Published in:

Journal of Hydrology

\section{Document Version:}

Peer reviewed version

Queen's University Belfast - Research Portal:

Link to publication record in Queen's University Belfast Research Portal

\begin{abstract}
Publisher rights
This is the author's version of a work that was accepted for publication in Journal of Hydrology. Changes resulting from the publishing process, such as peer review, editing, corrections, structural formatting, and other quality control mechanisms may not be reflected in this document. Changes may have been made to this work since it was submitted for publication. A definitive version was subsequently published in Journal of Hydrology, [VOL 486, (2013)]
\end{abstract}

\section{General rights}

Copyright for the publications made accessible via the Queen's University Belfast Research Portal is retained by the author(s) and / or other copyright owners and it is a condition of accessing these publications that users recognise and abide by the legal requirements associated with these rights.

\section{Take down policy}

The Research Portal is Queen's institutional repository that provides access to Queen's research output. Every effort has been made to ensure that content in the Research Portal does not infringe any person's rights, or applicable UK laws. If you discover content in the Research Portal that you believe breaches copyright or violates any law, please contact openaccess@qub.ac.uk. 


\section{Accepted Manuscript}

Developing an integrated hydrograph separation and lumped modelling approach to quantifying hydrological pathways in Irish river catchments

Ronan J. O'Brien, Bruce D. Misstear, Laurence W. Gill, Jenny L. Deakin, Ray Flynn

PII: S0022-1694(13)00080-2

DOI: http://dx.doi.org/10.1016/j.jhydrol.2013.01.034

Reference: HYDROL 18712

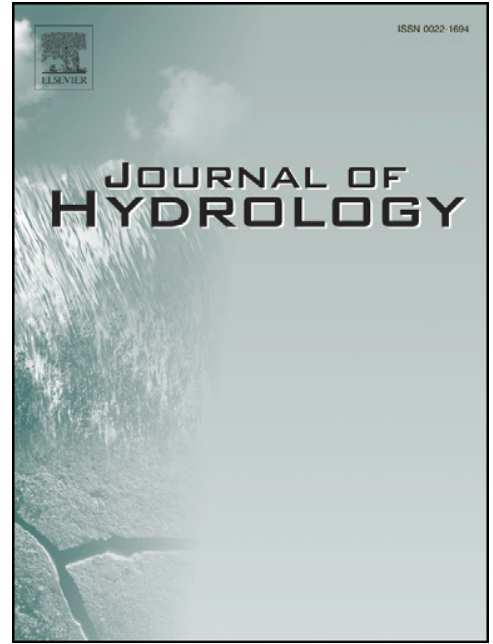

To appear in:

Journal of Hydrology

Received Date:

8 August 2012

Revised Date:

22 January 2013

Accepted Date:

28 January 2013

Please cite this article as: O'Brien, R.J., Misstear, B.D., Gill, L.W., Deakin, J.L., Flynn, R., Developing an integrated hydrograph separation and lumped modelling approach to quantifying hydrological pathways in Irish river catchments, Journal of Hydrology (2013), doi: http://dx.doi.org/10.1016/j.jhydrol.2013.01.034

This is a PDF file of an unedited manuscript that has been accepted for publication. As a service to our customers we are providing this early version of the manuscript. The manuscript will undergo copyediting, typesetting, and review of the resulting proof before it is published in its final form. Please note that during the production process errors may be discovered which could affect the content, and all legal disclaimers that apply to the journal pertain. 
1 Developing an integrated hydrograph separation and lumped modelling 2 approach to quantifying hydrological pathways in Irish river catchments

3 Ronan J. O’Brien, ${ }^{1 *}$ Bruce D. Misstear, ${ }^{1}$ Laurence W. Gill, ${ }^{1}$ Jenny L. Deakin, ${ }^{1}$

4 and Ray Flynn ${ }^{2}$

$5{ }^{1}$ Department of Civil, Structural and Environmental Engineering, Trinity College Dublin, Dublin, Ireland

$6 \quad{ }^{2}$ School of Planning, Architecture and Civil Engineering, Queen's University Belfast, Northern Ireland

$7 \quad$ Tel.:+353 1 8962045; fax +353 1 6773072. Email address: obrienrj@tcd.ie

8 Non-Standard Abbreviations. ${ }^{1}$

9 Abstract

10 An appreciation of the quantity of streamflow derived from the main hydrological pathways

11 involved in transporting diffuse contaminants is critical when addressing a wide range of

12 water resource management issues. In order to assess hydrological pathway contributions to

13 streams, it is necessary to provide feasible upper and lower bounds for flows in each pathway.

14 An important first step in this process is to provide reliable estimates of the slower responding

15 groundwater pathways and subsequently the quicker overland and interflow pathways. This

16 paper investigates the effectiveness of a multi-faceted approach applying different hydrograph

17 separation techniques, supplemented by lumped hydrological modelling, for calculating the

18 Baseflow Index (BFI), for the development of an integrated approach to hydrograph

19 separation. A semi-distributed, lumped and deterministic rainfall runoff model known as

20 NAM has been applied to ten catchments (ranging from 5 to $699 \mathrm{~km}^{2}$ ). While this modelling

21 approach is useful as a validation method, NAM itself is also an important tool for

22 investigation. These separation techniques provide a large variation in BFI, a difference of

230.741 predicted for BFI in a catchment with the less reliable fixed and sliding interval

24 methods and local minima turning point methods included. This variation is reduced to 0.167 with these methods omitted. The Boughton and Eckhardt algorithms, while quite subjective in

26 their use, provide quick and easily implemented approaches for obtaining physically realistic

27 hydrograph separations. It is observed that while the different separation techniques give

28 varying BFI values for each of the catchments, a recharge coefficient approach developed in ${ }^{1}$ NAM - Nedbør-Afstrømnings-Model", Danish software literally meaning rainfall runoff
model. 
Ireland, when applied in conjunction with the Master recession Curve Tabulation method,

Keywords: river hydrograph separation; catchment modelling; recharge coefficients

\section{$37 \quad 1 \quad$ Introduction} underlies the objective of most catchment studies, whether the aims of the study are flood prediction, power generation, ecosystem preservation and remediation, water resource management or contaminant transport. This has been the subject of many studies from over 70 years ago (Boussinesq, 1877; Horton, 1933) through the second half of the $20^{\text {th }}$ century (Pinder and Jones, 1969; Sklash and Farvolden, 1979; Nathan and McMahon, 1990; Chapman and Maxwell, 1996) up to recent times (Sivapalan et al., 2003; Brodie and Hostetler, 2005; Eckhardt, 2008; Santhi et al., 2008). Research has focused on simple separation approaches that relied heavily on the analyst's experience, such as graphical separation techniques, (Linsley, 1958; Linsley Jr et al., 1975; Frohlich et al., 1994; Szilagyi and Parlange, 1998) and

48 on less subjective means of separation such as filtering algorithms like the local minima 49 turning point separation method (Institute of Hydrology, 1980), the fixed and sliding interval 50 methods (Pettyjohn and Henning, 1979), the Lyne and Hollick one-parameter algorithm (Lyne and Hollick, 1979), the Boughton-(Boughton, 1993) and the Eckhardt- (Eckhardt, 2005) twoparameter algorithms and the three parameter IHACRES filter (Jakeman and Hornberger, 1993). Analysis of the hydrographs recession following a rainfall event has also attracted much investigation to interpret the discharge processes dominating. Many approaches have been taken to elucidate the linear (Barnes, 1939; Tallaksen, 1995) and non-linear effects present (Coutagne, 1948; Van de Griend et al., 2002) based on the analysis by Boussinesq

57 (1877), that was applied to river discharge data (Maillet, 1905; Horton, 1933). The 
provide an indication of the groundwater, and conversely the quick responding pathways, will contribute to the river hydrograph. This has been investigated internationally (Rorabaugh, 1964; Rutledge and Survey, 1998; Scanlon et al., 2002) and in the Irish setting (Misstear and Fitzsimons, 2007; Misstear et al., 2009). These studies all sought to further understand the origin of the water and the processes that sustain a river's flow, which still drives much of the research and legislation internationally today (Dunn et al., 2010; Gomi et al., 2010; Dahlke et al., 2011; Ockenden and Chappell, 2011). The Water Framework Directive (WFD, 2000) is considered one of the most comprehensive pieces of European Union (EU) water legislation written to date. In contrast to previous EU directives, the WFD takes an integrated view of the water cycle and its components. It is now recognised that an understanding of the hydrological processes involved in a catchment is vital to predicting environmental and ecological impacts resulting from changes in land use and management practices. This requires the identification of the important pathways transporting both diffuse and point source contaminants to rivers and aquatic ecosystems.

Ireland's hydrogeological setting is an important driver of these hydrological processes and is dominated by fracture flow within the bedrock aquifers. These aquifers range from poorly productive aquifers, capable of transmitting only small amounts to water through the fractured-bedrock pathways, to regional important aquifers that have the capacity to transmit larger volumes of water. The classification is based on criteria such as aquifer areal extent, transmissivity, potential well yields, etc as explain by Geological Survey of Ireland (2006).

\section{*Table 1*} responding surface pathways. Conceptually, the main flow pathways contributing to rivers in an Irish setting are: overland flow, interflow, shallow groundwater flow and deep groundwater flow, as shown on Figure 1. Overland flow is rainfall runoff over the land's surface and into the first few millimetres of soil. It is conceptualised as occurring when the soil becomes 
saturated, i.e. saturation excess overland flow, typical of many catchments in temperate climates (Bonell, 1993). Interflow is conceptualised as lateral subsurface flow in soils and subsoils and can occur under both saturated and unsaturated conditions. Shallow groundwater is the groundwater component that occurs in the more transmissive upper part of the fracturedbedrock aquifer, where there is generally greater weathering of the rock and often greater numbers of open fractures than at depth. Finally, deep groundwater is defined as the groundwater in the main body of the less transmissive aquifer below this upper weathered layer. All four pathways are conceptualised as potentially contributing to streamflow.

\section{*Figure 1*}

The aims of the research project (the Pathways project) are to achieve a better understanding of these hydrological pathways, the fate and transport of waterborne contaminants, and the subsequent impact of these contaminants on aquatic ecosystems in Irish catchments. The contaminants being investigated include phosphorus, nitrogen, sediments, pesticides and pathogens. The project is to develop a Catchment Management Tool (CMT) to assist the Irish Environmental Protection Agency and River Basin District managers in achieving the objectives of the WFD. As an important element of this research is to quantify the proportion of the river hydrograph that is derived from each of the main pathways, a reliable approach is required to identify the overland and subsurface pathways.

\section{The first step of this process is to calculate the contribution of the groundwater pathways} contributing to the hydrograph, regarded as the baseflow or contribution of both shallow and deep groundwater. When separating baseflow from the observed discharge, certain qualitative rules have been applied to aid in assessing separations. These rules of thumb allowed the investigator to ascertain if the results of techniques applied are realistic or act as guidance in graphical separations carried out by hand on available hydrographs. The Australian Rainfall and Runoff report on Baseflow for Catchment Simulation (Merz et al., 2009) summarises five such rules concisely as: 
1. Low flow conditions prior to the commencement of a flood event consist entirely of baseflow.

2. The rapid increase in river level relative to the surrounding groundwater level results in an increase in bank storage. The delayed return of this storage to the river causes

4. The baseflow recession will most likely follow an exponential decay function.

5. The baseflow hydrograph will rejoin the total hydrograph as quickflow ceases.

These five assumptions of baseflow separation were employed when assessing the techniques employed in the catchments.

129

\section{Study Catchments}

131 In Ireland, the major land use is grassland, which covers approximately two-thirds of the total

132 land area - and over 90\% of all agricultural land (Brogan et al., 2002). Brown earths and

133 Brown Podzolic type soils are common in the midlands and south, while gleyed soils are more

134 common in the north and west. Subsoils consist of glacial deposits, mainly tills, together with

135 peat, lascustrine deposits and alluvium (Archbold et al., 2009). The geological conditions of

136 Ireland are highly heterogeneous across the country, with variations in subsoil and bedrock

137 properties occuring over short distances. Examining the aquifer mapping available,

138 approximately $73.5 \%$ of aquifers are poorly productive ( $\mathrm{Pl}, \mathrm{Pu}$ or $\mathrm{Ll})$, with the more

139 productive karst aquifers generally occurring in the west of the country. Most of the eastern

140 half of the country receives between 750 and $1000 \mathrm{~mm}$ of rainfall in the year. Rainfall in the

141 west generally averages between 1000 and $1400 \mathrm{~mm}$. In many mountainous districts rainfall

142 exceeds $2000 \mathrm{~mm}$ per year. Hail and snow contribute relatively little to the precipitation

143 measured. The average annual potential evapotranspiration (PE) for the period 1971-2000 is

144 between 440 and $552 \mathrm{~mm}$ for inland and maritime stations, respectively (Collins et al., 2004).

145 Daily streamflow data are available from hydrometric stations maintained by the Office of

146 Public Works (OPW) and the Environmental Protection Agency (EPA), with higher temporal

147 resolution data available from a selection of these upon request. Three catchments were 

covering a range of different hydrological conditions. Supplementing these were three

150 catchments in the Slieve Aughty mountains located on the Galway, Clare border. Three catchments were then used from the Pathways Project, Mattock (Louth, Meath), Nuenna

152 (Kilkenny) and Glen Burn (Down). In these three catchments, data was obtained from four gauging stations that were specifically set up for this project. These supplementary catchments

154 all had discharge data at one hour intervals or less. The catchment locations are shown in

155 Figure 2, while Table 2 outlines the characteristics of these catchments.

*Figure 2*

*Table $2 *$

160

\section{Methods}

162 In order to quantify the contribution of the pathways, different techniques can be applied to

163 calculate the BFI. These techniques range from studying the characteristics of recessions,

164 using signal analysis methods, assessing geology, soil and subsoil cover, to implementing numerical models. Recession analysis, recursive digital filtering techniques, automated fixed and sliding interval approach, local minima turning point technique, recharge coefficient approach and lumped numerical modelling were used to constrain the quick responding flow

168 from the baseflow and, where possible, the four pathways of the conceptual model, as described in the following sections.

\section{$171 \quad 3.1 \quad$ Recession Analysis}

172 A recession period is the time following a rainfall event during which stream discharge

173 recedes until subsequent rainfall increases discharge once more. It has been observed in many

174 studies that the recession of the hydrograph can be approximated with a linear reservoir

175 (Horton, 1933; Nathan and McMahon, 1990; Chapman, 1999; Brodie and Hostetler, 2005).

176 Discharge from a linear reservoir, with no recharge occurring over the period, can be

177 expressed as: 
$178 \quad Q_{2}=Q_{0} \sigma^{-2} f \mathrm{~T}=Q_{0} k^{2}$

179 where $Q_{t}$ and $Q_{0}$ are the discharge at times $t$ and start of the recession, time 0 , and $\tau$ is the

180 response or turnover time of the reservoir. The term $e^{-(1 / /)}$ is usually termed the recession

181 constant $k$ and used to inform automated signal filtering techniques. This equation is obtained

182 from the solution to the water continuity equation:

$183 Q=-\frac{6}{d t}$

184 where $S$ is the storage of the reservoir $\left[\mathrm{L}^{3}\right]$, using the linear relationship of discharge to

185 storage:

186

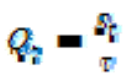

187 The general suitability of the assumption of the groundwater storage being a linear reservoir has been questioned as many recessions do not always form a straight line on a semi-

189 logarithm plot (Barnes, 1939; Chapman, 1999; Fenicia et al., 2006). However, it has been demonstrated that although simplistic in its approach to groundwater discharges, the linear

191 reservoir assumption, subject to incorporating recharge into the analysis, can suitably model

192 the groundwater behaviour in many catchments (Chapman, 1999). Where the groundwater

193 behaviour cannot be adequately modelled with a linear reservoir assumption, a non-linear

194 model should be used. Eq. (1) is shown to be the special case solution of the generalised non-

195 linear reservoir (Coutagne, 1948):

$196 Q_{n}=Q_{0}\left[1+(n-1) t / q_{0}\right]^{-n /(n-1)}$

197 where $\tau_{0}=S_{0} / Q_{0}$ is the turnover time at time zero and $n$ is the measure of the non-linearity of

198 the reservoir.

199

200 Another approach to modelling this situation with a linear reservoir is to split the non-linear

201 reservoir into a number of smaller reservoirs in parallel that could each be modelled as being

202 linear (Tallaksen, 1995). This is the approach taken in this paper for calculating the $\tau$ related to 
where ${ }^{*},{ }_{I}, s$, and $_{D}$ refer to combined, overland, interflow, shallow and deep groundwater storages respectively.

In order to identify these $\tau$ values for each of the pathways present, Master Recession Curves (MRC) are constructed. This is achieved by plotting many recessions side by side, as per the tabulation method (Johnson et al., 1956). Analysis of the MRC allows the characteristic response of a catchment at different discharge levels to be inferred from the rate of recession

213 of the discharges.

214

\section{$215 \quad 3.2 \quad$ Recursive digital filters}

216 This technique is based upon a recursive digital filter commonly applied in signal analysis and

217 processing. The basis of this method is that filtering out high-frequency signals is analogous to

218 the separation of 'low-frequency' slow response flow from high-frequency quick response

219 flow. The main drawback of this method is that the selection of parameters can be subjective

220 (though not always) and physically unrealistic.

221 Three types of recursive digital filters are compared to each other. These are the 'oneparameter', and two different 'two-parameter' algorithms.

\section{$224 \quad 3.2 .1 \quad$ One Parameter}

The first 'one-parameter' algorithm (Lyne and Hollick, 1979) was shown to maintain baseflow at a constant value once overland flow had ceased and hence updated (Chapman and Maxwell, 1996) to a form that has the groundwater flow being a the previous time interval: 
subject to the condition that constant and $t$ is the time step.

\subsubsection{Two Parameter}

237

The most widely used 'two-parameter' algorithm, the Boughton-two-parameter algorithm (Boughton, 1993) was developed from the 'one-parameter' algorithm. It replaces $(1-k)$ with $C$ to add another degree of flexibility to the algorithm.

The addition of parameter $C$, although allowing the algorithm to be more flexible, reduces its objectivity as $C$ must be chosen by the user of the algorithm. If an optimisation programme is implemented to select a value for $\mathcal{C}$, this parameter $\mathcal{C}$ will be increased until the entire streamflow that is observed, derives from groundwater flow. Therefore $C$ should be selected with the objective of achieving the correct point

Eckhardt (2005) developed a two-parameter filter in an attempt to remove the for quick response flow to end on the hydrograph. 

satisfactory separation is computed. the 'one-parameter' algorithm (Chapman, 1999) and due to its widespread use and

Three methods, two of which are available in the HYSEP model (Sloto and Crouse, 1996), response flow.

275

276 The fixed and sliding interval methods are contained within the HYSEP, a hydrograph 277 separation model from the United States Geological Survey (USGS) that estimates the base 278 flow component of streamflow. These two methods were both developed by Pettyjohn and

279 Henning (1979). The fixed interval method involves identifying the minimum discharge

280 within an interval and setting it as the baseflow for that interval. The sliding interval method is

281 analogous to the fixed interval method, but the interval moves forward in the discharge series

282 by one time step each time, with the minimum value of the interval being set as the value of

283 baseflow at the median of the interval. 
284 The local minimum turning point technique (Institute of Hydrology, 1980) involves the use of

285 the fixed interval method to identify local minima in each non-intersecting interval. The

286 minimum of each interval is then compared to two neighbouring minima to establish if it is

287 less than $90 \%$ of these values. If it is, these minima are termed turning points, which are then

288 connected to define the baseflow series.

289 The interval in each of these methods is calculated from the approximation for the time from

290 the peak of an event to the end of quickflow (Linsley et al., 1949):

$291 N=0.83 A^{9.2}$

292 where $A$ is the catchment area in $\mathrm{km}^{2}$. The interval is calculated as being twice this time. $N=$

2932.5 days is also a commonly chosen value (Institute of Hydrology, 1980). The output of the

294 local minima turning point method is compared, calculating $N$ with both methods. The choice

295 of the time base $N$ has a large effect on the BFI calculated, as the minimum value chosen for

296 separations is sensitive to this $N$ value (Misstear and Fitzsimons, 2007).

297

$298 \quad 3.4 \quad$ Recharge coefficients

299 Recharge to aquifers can be estimated by calculating effective rainfall, using a soil moisture

300 budget technique, and then multiplying by recharge coefficients to indicate the proportion of

301 effective rainfall contributing to groundwater recharge (Misstear et al., 2009). Table 3

302 describes the hydrological setting relating to each recharge coefficient and the range over

303 which these coefficients tend to vary. These recharge coefficients are identified from soil and

304 subsoil GIS data for the catchment in conjunction with a recharge coefficient table (Hunter

305 Williams et al., 2012 (In Press)).

306

307

*Table 3*

308

309 Effective rainfall is calculated as total rainfall less actual evapotranspiration. Actual

310 evapotranspiration is estimated from recorded values of potential evapotranspiration and a soil

311 moisture budgeting approach such as the FAO Penman-Monteith method (Allen et al., 1998).

312 As previously mentioned, aquifers in Ireland have been rated from regionally important, to 
313 locally important, to poor. Due to the low storativity characteristics of many aquifer types,

314 there is a limit to the amount of recharge that can be accepted by the aquifer. A cap on the

315 amount of recharge is defined for the locally important and poorly productive and aquifers:

$316200 \mathrm{~mm} / \mathrm{yr}$ for locally important aquifers and $100 \mathrm{~mm} / \mathrm{yr}$ in poor aquifers (Working Group on

317 Groundwater, 2005). GIS shapefiles for subsoil, soil and aquifer mapping from the Geological

318 Survey of Ireland, and rainfall and evapotranspiration data, collected from the study site, were

319 utilised to calculate the recharge coefficients. The soil and subsoil shapefiles indicate the

320 permeability of the overburden above the aquifer, while the aquifer shapefile defines the

321 productivity class of the aquifer and thus if it is limited in the recharge it may receive. The

322 vulnerability shapefiles, derived from mapping carried out to rate the risk of contaminants

323 entering the aquifers, are also informative as the approach used to develop these is analogous

324 to the method required for calculating the recharge coefficients. The recharge coefficient

325 approach therefore provides a basis for separating the quicker response pathways

326 (conceptually overland flow and interflow) from the slower response pathways (shallow and

327 deep groundwater).

328

$329 \quad 3.5 \quad$ Hydrological Modelling

330 Hydrological models can help to inform the decisions of catchment and river basin managers,

331 though they are not solely decision making tools, but are part of the investigation process.

332 Hydrological modelling in this research was carried out with the NAM model, as described

333 below.

$334 \quad 3.5 .1 \quad \underline{N A M}$

335 The Danish "Nedbør-Afstrømnings-Model", literally meaning rainfall runoff model, was

336 developed in 1973 by the Department of Hydrodynamics and Water Resources at the

337 Technical University of Denmark (Nielsen and Hansen, 1973). It is a deterministic, lumped,

338 conceptual rainfall-runoff model for simulating the hydrological cycle.

339

340 NAM was applied in Ireland in many catchments as part of a previous study concerned with

341 groundwater-surface water interactions (RPS, 2008). The conceptual model followed was a

342 simpler three-pathway (overland, intermediate and groundwater) model compared with the 
343 four-pathway conceptual model of this paper. Also, the previous study did not involve

344 detailed catchment studies to help validate the model results. Building upon this work, NAM

345 is considered to be a very useful tool in catchment modelling in the Irish setting. It has the

346 capacity to simulate the four pathways of the conceptual model, while the model's lumped

347 approach does not require complex detailed input data (which is generally not available for

348 most catchments). This lumped approach also has the flexibility to be adapted to the variable

349 geological settings encountered in Ireland.

350

351 The NAM model represents the various hydrograph components using a moisture budgeting

352 approach for different storages. The storages behave much like the linear reservoirs described

353 by Equation 1. The form of model structure which was applied in this research involved four

354 storages: snow storage was omitted and the lower storage was split into two storages, one for

355 shallow and one for deep groundwater. Overland flow and interflow were modelled as

356 discharges from the uppermost storage; interflow was modelled as discharge from the bottom

357 of this storage; while overland flow was overtopping discharge from this storage analogous to

358 saturation excess flow. A middle storage monitored soil moisture deficit in the catchment and

359 acted as a control for overland flow, interflow and recharge occurrence. The NAM structure is

360 shown in Figure 3.

361

362 *Figure $3 *$

363

$364 \quad 4$ Results

365

366 Master Recession Curve Analysis

367 Employing the recession analysis methods, Master Recession Curves were constructed for the

368 study catchments. It was assumed that the two faster responding equations (those with the two

369 steepest recessions) fitted to the data were the overland flow and interflow pathways, with the

370 two slowest responding equations the shallow and deep groundwater pathways. The recession

371 constants were then identified from each of the equations for these recession segments as 

shown in Table 4.

378

*Figure 4*

380

381

*Table 4*

382

383

\subsection{Recursive digital filters}

384 Following on from the identification of the recession constants identified in the recession

385 analysis, the Boughton two-parameter and Eckhardt digital filter methods were applied. These were calibrated until the five criteria outlined previously had been satisfied adequately. This was achieved manually by adjusting the $C$ parameter for the Boughton algorithm and the $B F I_{\text {max }}$ parameter for the Eckhart algorithm, while visually inspecting the hydrograph separations, while assessing the BFI obtained. An example of a separation obtained for quick and slow response pathways in the Blackwater Fyanstown catchment is presented in Figure 5.

391 Table 5 contains the BFI values computed for the catchment using the 'best' calibrations for

392 the Boughton and Eckhardt algorithms This was based on BFI calculated from the MRC

393 analysis, the recharge coefficient approach and NAM modelling, as well as a qualitative

394 assessment of geological conditions.

395

*Figure 5*

397

*Table 5*

399

\subsection{Recharge coefficients}


401 The recharge coefficients were calculated for the catchments by examining the GIS layers for

402 soil, subsoil and aquifer type. An example of the GIS data applied to calculate these

403 coefficients for the Mattock catchment are presented in Figure 6. The area of each soil and

404 subsoil type, with reference to Table 3, allowed the recharge coefficient to be calculated for

405 each soil and subsoil combination with the overall catchment recharge coefficient computed

406 from the average of these, weighted by area. These coefficients were then assessed in

407 conjunction with hydrologically effective precipitation (rainfall - actual evapotranspiration) to

408 calculate the annual BFI for the study catchments. Table 7 displays the BFI values calculated

409 applying this approach, with the mean values for the recharge coefficients taken from the

410 recharge coefficient table (Table 3).

411

$412 *$ Figure 6*

413

$414 \quad 4.4 \quad$ Fixed and sliding interval, and local minima turning point 415 separation methods

416 The two HYSEP filters and the local minima turning point method were also applied to the

417 study catchments. The standard interval $(2 N)$ for the local minima turning point method is 5

418 days, which was adopted, but the interval was also calculated from Equation 10. Table 7

419 includes the BFI values obtained using three filter methods for the study catchments, with two

420 values for BFI calculated for the local minima turning point method employing a 5 day

421 interval and calculated interval. Figure 7 illustrates separations using this approach in the

422 Blackwater Fyanstown catchment.

$424 *$ Figure $7 *$

425

\subsection{Hydrological Modelling}

427 Finally, NAM was applied to the catchments, with model parameters initially selected based

428 on guidance from the user manual, MRC recession constants for estimates of time constants

429 within the model and from previous studies implementing the model ((Shamsudin and

430 Hashim, 2007; RPS, 2008). Following this, observed discharge assisted with the calibration of 

objective functions are applied to assess the performance of the model, different calibrations are obtained. The Nash - Sutcliffe $\mathrm{R}^{2}$ value (Nash and Sutcliffe, 1970) was utilised to assess the goodness of fit for the simulated against the observed discharge with the $\mathrm{R}^{2}$ values shown

435 in Table 6. Simulations were carried out using the smallest time step of rainfall data available. This allowed for improved simulation of peaks in quickly responding catchments, particularly those with small BFI values. An example of the simulated groundwater pathways in the presented in Table 6 and Table 7.

*Table $6^{*}$

\section{Discussion}

448 Table 7 shows that there are large variations in estimates of BFIs obtained by applying the

449 different separation techniques. Even within some of the techniques there is much subjectivity depending on what parameters are chosen and how the final separations are selected as being

451 the most appropriate. Overall it is observed that those catchments with higher BFI values

452 correspond to the catchments with more productive aquifers underlying the soils and subsoils 453 of which they are predominately derived. This is evident in the case of the Nuenna

454 (Monument), which is underlain by a regionally important aquifer with diffuse karst preset.

The Nuenna (Monument) has a NAM BFI value greater than 0.87 , which when compared with

456 the Glen Burn (Outlet) catchment, underlain by a poorly productive aquifer with a NAM BFI of less than 0.13, emphasises the importance of the aquifer classification within a catchment. 
461 the assumption of each behaving like a linear reservoir, which is deemed less appropriate for

462 the quicker responding overland flow and interflow pathways. Of importance also, is the

463 calculation of the recession parameter $\tau$ for the slower pathways. The $\tau$ is computed from the

464 equations fitted to the recessions; these equations are fitted manually. This $\tau$ value is used to

465 calculate the value of $k$ for the Boughton and Eckhardt algorithms, but also provides an

466 estimate of the time constant in NAM for the groundwater pathways. Figure 4 provides an

467 example of the MRC tabulation method for the Blackwater Fyanstown catchment. This

468 demonstrates that the slope of each segment corresponds to a different pathway; the slowest

469 responding pathway corresponds with the smallest $\tau$ value, while the next smallest $\tau$

470 corresponds to a superposition of the two slowest responding pathways.

471

472 The fixed interval, sliding interval and local minima turning point techniques appear to be the

473 least subjective, although there is some doubt as to whether it is better to calculate the interval

$474(2 N)$, using Equation 10, or implement a predefined value of 5 days. As catchment size

475 decreases to the point where the $N$ calculation provides an interval of less than 5 days; this

476 results in the choice of the lower $N$ value giving a higher BFI value. While Equation 10

477 provides an objective means of calculating which $N$ to use, experience is required to select the

$478 N$ that will provide a BFI value that is compatible with the recharge coefficients approach. An

479 alternative to using Equation 10, is to assess the response of the groundwater levels within a

480 borehole located close to the river being studied (Misstear and Fitzsimons, 2007). The $N$ value

481 is selected to match the rising and falling response of the water level measured within the

482 borehole. This provides a more realistic shape for the separation but may not fully address the

483 overestimation of the BFI, as this method still requires the turning points to be on the

484 hydrograph to define the location of baseflow. This results in the selection of turning points

485 during rainfall events that are much higher than would be plausible. This occurs during the

486 peaks in 1992, 1993 and 1994 in Figure 7, resulting in baseflow contributions in excess of

487 what would be considered feasible. Also if few turning points are identified, the baseflow may

488 be defined as a straight line over a long period, set to the observed discharge in locations

489 where the baseflow is defined as being greater than observed discharge by this straight line.

490 This occurs in 1995 in Figure 7 when the baseflow contribution is low compared with the 
491

492

493

494

495

496

497

498

499

500

501

502

503

504

505

506

507

508

509

510

511

512

513

514

515

516

517

518

519

520

other years. In this case no turning point was identified during the series of peaks at the beginning of 1995 . As a result the baseflow is defined by a turning point during the start of 1994 and in late 1995. If a smaller interval than the 5 days was applied in the analysis, a turning point may have been identified during this period, redefining the baseflow contribution. This lack of turning points influences only the local minima turning point technique, but the overestimation caused by choosing baseflow values from the observed discharge affects all three of these methods.

Upon inspecting Figure 7, it is clear that the separations from the fixed interval, sliding interval and local minima turning point techniques appear unrealistic when set against the five requirements of baseflow outlined in the introduction to this paper. It is also observed in Figure 7, that both the sliding and fixed interval techniques follow the shape of the hydrograph with no recession observed after an event occurs. While the local minima turning point method provides lower estimates of baseflow, the separated baseflow fails to continue to recede after the event begins. Additionally, the peak of the baseflow always occurs as it rejoins the hydrograph, rather than peaking after the event peak, then rejoining the hydrograph following an exponential recession thereafter.

The Boughton and Eckhardt algorithms, however, do satisfy these requirements. In Figure 5, it is observed that recessions occur for a short period after the event has begun, with (though not always) the peak of the baseflow occurring after the peak of the hydrograph, followed by an exponential recession until the baseflow rejoins with the hydrograph. However, the application of these methods relies on the operator having a previous estimate of BFI.

Although the $k$ value can be informed from MRC analysis, having the effect of reducing the independence of this separation method, the remaining $C$ parameter in the Boughton algorithm and the $\mathrm{BFI}_{\max }$ parameter in the Eckhardt algorithm are free variables which are very sensitive in relation to the BFI value calculated. While the $C$ parameter is based originally on having a value of $1-k$, this additional $C$ parameter is employed as a 'free variable' that can be adjusted as necessary to obtain the baseflow separation required. This $C$ parameter is therefore disconnected from its 1 - $k$ origins and as such is picked from subjective experience, making it 
521 difficult to replicate the separation obtained. The $\mathrm{BFI}_{\max }$ parameter, however, has an almost

522 complete control over the value of BFI as can be seen from Table 8, where two catchments

523 where chosen, Nuenna (Monument) with a very high BFI and Glen Burn catchment with a

524 low BFI for Irish conditions. It is evident here that the subjective choice of $\mathrm{BFI}_{\max }$ almost

525 completely defines BFI, whereas the $k$ value has almost no influence on overall volume but

526 will affect the baseflow shape. This results in the user of the algorithm needing to know the

527 BFI of the catchment in advance, and also to have an idea of the baseflow hydrograph shape.

528 Nevertheless, these algorithms are useful for obtaining separations of time series data that

529 have exponential recessions with BFI values based on prior knowledge. Thus, they are of

530 more value for understanding baseflow distribution in the hydrograph, rather than inferring

531 BFI values.

532

$533 *$ Table $8^{*}$

534

535 An examination of the BFI values calculated using the different approaches, presented in

536 Table 7, allows the variation in BFI between methods to be evaluated. The recharge

537 coefficients approach provides a physically-based framework within which to make initial

538 estimates of BFI based on the depth to bedrock and the permeability of the overburden. This is

539 therefore viewed as a guiding BFI value for the amount of water feeding into the groundwater

540 pathways. This groundwater, conceptually, is thus observed as maintaining baseflow. By

541 choosing the mean value for recharge coefficients from Table 3, the subjectivity of the

542 computed separations is minimised. Adopting this as starting point in the appraisal of the

543 different methods it would appear that the HYSEP methods and the local minima turning

544 point method, consistently overestimate the BFI value. The Master Recession Curve

545 tabulation method tends to provide a reasonable initial estimate for BFI calculation, analogous

546 to the recharge coefficient approach. Unlike the recharge coefficient approach, the MRC uses

547 streamflow data to identify general characteristics of a catchment by observing trends in

548 recessions following rainfall events. Due to this analysis of streamflow, rather than just

549 geological unit analysis, the MRC approach estimates the flows in catchments with significant

550 karst-derived groundwater inputs (i.e. the Deel and the Nuenna) with more success, as typical 
551 karst features such as swallow holes and conduits have significant impacts on hydrology

552 across a wider spectrum of the observed streamflows. The subjectivity of the formation of the

553 MRC and identifying the breaks in slope of the MRC are of concern, but when applied in

554 conjunction with the recharge coefficient approach and NAM, it provides a useful way of

555 informing the recession parameter of the Boughton and Eckhardt algorithms. NAM is

556 employed both as a validation method, but also as a means of investigation in itself as

557 optimisation methods may suggest that the conceptual model of a catchment is incorrect if

558 very different BFI values are obtained. In this manner the iterative nature of calculating the

559 BFI value for the different catchments should be appreciated.

560

5616 Conclusions

562 The calculation of the Baseflow Index of a catchment is both a difficult and subjective task

563 due to the inability of current technology to measure baseflow contributions accurately on a

564 catchment scale. After implementing many different hydrograph separation techniques and

565 applying the NAM modelling as a means of investigating the contribution of pathways to the

566 river hydrograph, the Master Recession Curve analysis, the recharge coefficient approach and

567 the NAM modelling are identified as providing an integrated approach for calculating the

568 Baseflow Index (BFI). This integrated approach put forward in this paper provides the

569 framework for calculating a reliable BFI, generally within a small range, which is consistent

570 with discharge data and the geological setting of the catchment in question. The Master

571 Recession Curve approach of identifying all the responses present and not just a quick and

572 slow response allows the baseflow to be identified with more confidence. The recharge

573 coefficients method indicates the contribution of effective rainfall to quick response and

574 groundwater pathways taking account of the geological setting of the catchment, though may

575 struggle with recharge that may occur in karst settings due to features such as swallow holes

576 recharging the aquifer with surface runoff. The hydrological pathway modelling using NAM

577 then allows the checking of the viability of the conceptual separations. This modelling also

578 provides a means of investigation of what type of separation is possible with the rainfall and

579 evapotranspiration data available.

580 
581 This integrated approach therefore brings together the rainfall input to the catchment, the

582 geological setting of the catchment and the catchment outputs of discharge measured in the

583 river and evapotranspiration, thereby providing a more reliable BFI value than one based on a

584 single approach. The Boughton and Eckhardt methods do not necessarily provide a reliable

585 BFI value estimate due to their subjectivity, but are a useful means of obtaining a baseflow

586 time series that satisfies the five objectives of baseflow separation outlined in Section 1. The

587 HYSEP and local minima turning point techniques, while providing feasible BFI values if a

588 suitable interval is chosen, do not provide reliable baseflow hydrographs when applied on

589 their own.

590

591 Acknowledgements

592 The work described in this paper is based on a project which was carried out for the Environmental

593 Protection Agency under the STRIVE Programme 2007-2013. The project title was "2007-W-CD-1-S1:

594 Pathways Project". The authors would like to thank other members of the project team, including Marie

595 Archbold, together with the members of the project steering group: A. Wemaere (Environmental

596 Protection Agency), L. Sheils (Environmental Protection Agency), D. Daly (Environmental Protection

597 Agency), N. Hunter-Williams (Geological Survey of Ireland), I. Cluckie (Swansea University), S.

598 Fletcher (ret-Environment Agency), V. Fitzsimons (Scottish Environmental Protection Agency), P.

599 Jordan (University of Ulster) and S. Rekolainen (Finnish Environment Institute). The author would also

600 like to thank Met Eireann, Environmental Protection Agency and the Office of Public Works for

601 providing the hydrometric data for this paper.

602

References

604 Allen, R., Pereira, L., Raes, D., Smith, M., 1998. Crop evapotranspiration-

605

Guidelines for computing crop water requirements-FAO Irrigation and

606 drainage paper 56. FAO, Rome, 300.

607 Archbold, M. et al., 2009. Contaminant Movement and Attenuation along

608 Pathways from the Land Surface to Aquatic Receptors - A Review. In:

609 Agency, E.P. (Ed.). EPA STRIVE 2007-W-CD-1-S1. 
610 Barnes, B., 1939. The structure of discharge recession curves. Trans. Am.

611 Geophys. Union, 20(4): 721-725.

612 Bonell, M., 1993. Progress in the understanding of runoff generation dynamics 613 in forests. Journal of Hydrology, 150(2-4): 217-275.

614 Boughton, W., 1993. A hydrograph-based model for estimating the water yield 615 of ungauged catchments. INSTITUTION OF ENGINEERS,

616 AUSTRALIA, pp. 317-317.

617 Boussinesq, J., 1877. Théorie de l'écoulement tourbillant. Mem. Présentés par 618 Divers Savants Acad. Sci. Inst. Fr, 23(46-50): 6.5.

619 Brodie, R., Hostetler, J., 2005. A review of techniques for analysing baseflow 620 from stream hydrographs.

621 Brogan, J., Carty, G., Crowe, M., Agency, I.E.P., 2002. Towards Setting 622 Environmental Quality Objectives for Soil: Developing a Soil 623 Protection Strategy for Ireland; a Discussion Document. 624 Environmental Protection Agency.

625 Chapman, T., 1999. A comparison of algorithms for stream flow recession and 626 baseflow separation. Hydrological Processes, 13(5): 701-714.

627 Chapman, T., Maxwell, A., 1996. Baseflow separation-comparison of 628 numerical methods with tracer experiments. Institution of Engineers, $629 \quad$ Australia, pp. 539.

630 Collins, J., Larney, F., Morgan, M., 2004. Climate and soil management. 631 Climate, Weather and Irish Agriculture'(eds. T. Keane and JF Collins) 632 2nd Edition. AGMET, Dublin.

633 Coutagne, A., 1948. Etude générale des variations de débits en fonction des 634 facteurs qui les conditionnent, 2ème partie: Les variations de débit en 
635

636

637

638

639

640

641

642

643

644

645

646

647

648

649

650

651

652

653

654

655

656

657

658

période non influencée par les precipitations. La Houille Blanche: 416436.

Dahlke, H.E. et al., 2011. Dissecting the variable source area conceptSubsurface flow pathways and water mixing processes in a hillslope. Journal of Hydrology.

DELG/EPA/GSI, 1999. Groundwater Protection Schemes, Department of the Environment and Local

Government, Environmental Protection Agency and Geological Survey of Ireland.

Dunn, S., Birkel, C., Tetzlaff, D., Soulsby, C., 2010. Transit time distributions of a conceptual model: their characteristics and sensitivities. Hydrological Processes, 24(12): 1719-1729.

Eckhardt, K., 2005. How to construct recursive digital filters for baseflow separation. Hydrological Processes, 19(2): 507-515.

Eckhardt, K., 2008. A comparison of baseflow indices, which were calculated with seven different baseflow separation methods. Journal of Hydrology, 352(1): 168-173.

Fenicia, F., Savenije, H.H.G., Matgen, P., Pfister, L., 2006. Is the groundwater reservoir linear? Learning from data in hydrological modelling. Hydrology and Earth System Sciences, 10(1): 139-150.

Frohlich, K., Frohlich, W., Wittenberg, H., 1994. Determination of groundwater recharge by baseflow separation: regional analysis in northeast China. IAHS Publications-Series of Proceedings and Reports-Intern Assoc Hydrological Sciences, 221: 69-76. 
659 Geological Survey of Ireland, 2006. Aquifer Categories, Dublin Ireland, pp.

660 http://www.gsi.ie/NR/rdonlyres/01C4199F-A257-48A0-A963-

$661 \quad \underline{\text { 5CB65A779F6E/0/aquifer_classification_Oct06.pdf. }}$

662 Gomi, T. et al., 2010. Evaluation of storm runoff pathways in steep nested

663 catchments draining a Japanese cypress forest in central Japan: a

664 geochemical approach. Hydrological Processes, 24(5): 550-566.

665 Horton, R., 1933. The role of infiltration in the hydrologic cycle. Trans. Am.

666 Geophys. Union, 14: 446-460.

667 Hunter Williams, N.H., Misstear, B.D.R., Daly, D., 2012 (In Press).

668 Development of a national groundwater recharge map for the Republic

669 of Ireland. Quarterly Journal of Engineering geology and

$670 \quad$ Hydrogeology.

671 Institute of Hydrology, 1980. Low Flow Studies Report, Resources Report 1,

672 Oxon, Wallingford, U.K.

673 Jakeman, A., Hornberger, G., 1993. How much complexity is warranted in a

674 rainfall-runoff model? Water Resources Research, 29(8): 2637-2650.

675 Johnson, E.A., Dils, R.E., Station, S.F.E., 1956. Outline for Compiling

676 Precipitation, Runoff and Ground Water Data from Small Watersheds.

677 Southeastern Forest Experiment Station, US Dept. of Agriculture,

$678 \quad$ Forest Service.

679 Linsley Jr, R.K., Kohler, M.A., Paulhus, J.L.H., 1975. Hydrology for

$680 \quad$ engineers.

681 Linsley, K., 1958. Paulhus,'Hydrology for Engineers'. McGraw-Hill.

682 Linsley, R.K., Maidment, D.R., Mays, L.W., 1949. Applied hydrology. Tata

683 McGraw-Hill Education. 
684 Lyne, V., Hollick, M., 1979. Stochastic time-varying rainfall-runoff 685 modelling, pp. 89-92.

686 Maillet, E.T., 1905. Essais d'hydraulique souterraine \& fluviale. A. Hermann.

687 Merz, S.K. et al., 2009. AUSTRALIAN RAINFALL AND RUNOFF

688 REVISON PROJECT 7: BASEFLOW FOR CATCHMENT

689 SIMULATION.

690 Misstear, B., Brown, L., Daly, D., 2009. A methodology for making initial

691 estimates of groundwater recharge from groundwater vulnerability

692 mapping. Hydrogeology Journal, 17(2): 275-285.

693 Misstear, B., Fitzsimons, V., 2007. Estimating groundwater recharge in

694 fractured bedrock aquifers in Ireland. Taylor \& Francis Group, pp. 243.

695 Nash, J., Sutcliffe, J., 1970. River flow forecasting through conceptual models

696 part I--A discussion of principles. Journal of Hydrology, 10(3): 282-

697290.

698 Nathan, R., McMahon, T., 1990. Evaluation of Automated Techniques for

699 Baseflow and Recession Analysis. Water Resources Research, 26(7):

$700 \quad 1465-1473$.

701 Nielsen, S.A., Hansen, E., 1973. Numerical simulation of the rainfall-runoff

702 process on a daily basis. Nordic Hydrology, 4(3): 171-190.

703 Ockenden, M., Chappell, N., 2011. Identification of the dominant runoff

704 pathways from data-based mechanistic modelling of nested catchments

705 in temperate UK. Journal of Hydrology.

706 Pettyjohn, W.A., Henning, R.J., 1979. Preliminary estimate of regional

707 effective groundwater recharge rates in Ohio. 
708 Pinder, G., Jones, J., 1969. Determination of the ground-water component of

709 peak discharge from the chemistry of total runoff.

710 Rorabaugh, M., 1964. Estimating changes in bank storage and groundwater

711 contribution to streamflow. International Association of Scientific

$712 \quad$ Hydrology, 63: 432-441.

713 RPS, 2008. Further Characterisation Study: An Integrated Approach to

714 Quantifying Groundwater and Surface Water Contributions of Stream

$715 \quad$ Flow.

716 Rutledge, A., Survey, G., 1998. Computer programs for describing the

717 recession of ground-water discharge and for estimating mean ground-

718 water recharge and discharge from streamflow records: Update. US

719 Department of the Interior, US Geological Survey.

720 Santhi, C., Allen, P., Muttiah, R., Arnold, J., Tuppad, P., 2008. Regional

721 estimation of base flow for the conterminous United States by

722 hydrologic landscape regions. Journal of Hydrology, 351(1): 139-153.

723 Scanlon, B.R., Healy, R.W., Cook, P.G., 2002. Choosing appropriate

724 techniques for quantifying groundwater recharge. Hydrogeology

725 Journal, 10(1): 18-39.

726 Shamsudin, S., Hashim, N., 2007. Rainfall runoff simulation using MIKE11

727 NAM. Jurnal Kejuruteraan Awam, 14(2): 26-38.

728 Sivapalan, M. et al., 2003. IAHS Decade on Predictions in Ungauged Basins

729 (PUB), 2003-2012: Shaping an exciting future for the hydrological

730 sciences. Hydrological Sciences Journal, 48(6): 857-880. 
731 Sklash, M., Farvolden, R., 1979. The role of groundwater in storm runoff.

732 Contemporary hydrogeology: the George Burke Maxey memorial

733 volume: 45 .

734 Sloto, R.A., Crouse, M.Y., 1996. HYSEP: A computer program for

735 streamflow hydrograph separation and analysis. USGS Branch of

736 Information Services, Box 25286, Denver Federal Center, Denver, CO

$737 \quad$ 80225(USA).[nd].

738 Szilagyi, J., Parlange, M.B., 1998. Baseflow separation based on analytical

739 solutions of the Boussinesq equation. Journal of Hydrology, 204(1):

$740 \quad 251-260$.

741 Tallaksen, L.M., 1995. A review of baseflow recession analysis. Journal of

$742 \quad$ Hydrology, 165(1-4): 349-370.

743 Van de Griend, A.A., De Vries, J.J., Seyhan, E., 2002. Groundwater discharge

744 from areas with a variable specific drainage resistance. Journal of

$745 \quad$ Hydrology, 259(1): 203-220.

746 WFD, W.F.D., 2000. Directive 2000/60. EC of the European Parliament and

$747 \quad$ of the Council of, 23.

748 Working Group on Groundwater, 2005. Water Framework Directive (WFD)

749 Pressures and impacts assessment methodology: guidance on the

750 assessment of the impact of groundwater abstractions. In: Geological

751 Survey of Ireland, E.P.A., and River Basin Districts Coordinating

752 Authorities, (Ed.), Dublin. 
754 Figure 1. Pathways present in poorly productive and productive aquifers on the left and right respectively (J Deakin 2012: after N. Hunter-Williams and D. Daly)

756 Figure 2. Study catchment locations.

757 Figure 3. NAM structure schematic

758 Figure 4. Master Recession Curve, Tabulation Method for Blackwater (Kells) Fyanstown.

759 Figure 5. Boughton and Eckhardt baseflow separations for Blackwater Fyanstown.

760 Figure 6. Mattock soils and subsoils GIS data.

761 Figure 7. Fixed and Sliding Interval, and Smoothed Minima Turning Point methods for

762 Blackwater Fyanstown.

763 Figure 8. NAM modelled groundwater pathways for Blackwater. 
765 Table 1. Irish aquifer classifications (DELG/EPA/GSI, 1999).

Rf Regionally Important Aquifer - Fissured bedrock

Rk Regionally Important Aquifer - Karstified

Rkd Regionally Important Aquifer - Karstified (diffuse)

Rkc Regionally Important Aquifer - Karstified (conduit)

Lm Locally Important Aquifer - Moderately productive

Lk Locally Important Aquifer - Karstified

Ll Locally Important Aquifer - Moderately productive only in local zones

Pl Poor Aquifer - Unproductive except in local zones

$\mathrm{Pu} \quad$ Poor Aquifer - Generally unproductive 
767 Table 2. Study catchment characteristics.

\begin{tabular}{|c|c|c|c|c|c|c|}
\hline \multirow[t]{3}{*}{ Catchment } & \multirow[t]{2}{*}{ Area } & \multicolumn{5}{|c|}{ Catchment Descriptors } \\
\hline & & $\underline{\text { Land Use }}$ & $\begin{array}{c}\underline{\text { Aquifer }} \\
\text { Classification } \\
\end{array}$ & $\underline{\text { Annual }}$ Rainfall & $\underline{\text { Annual }} \underline{\underline{\text { Evapotranspiration }}}$ & $\underline{\text { Runoff }}$ \\
\hline & $\mathbf{k m}^{2}$ & Тype (\%) & Тype (\%) & $\mathbf{m m}$ & Mm & $\mathbf{m m}$ \\
\hline Deel & 283.1 & Pasture (78.6) & $\mathrm{Ll}(88.1)$ & 973 & 481 & 492 \\
\hline Blackwater (Kells) & 699 & Pasture (80.1) & Pl (74.1) & 1026 & & 535 \\
\hline Fyanstown & 187.6 & Pasture (86.5) & $\begin{array}{l}\text { Ll (34.7), } \\
\text { Pl (59.7) }\end{array}$ & 1020 & & 545 \\
\hline Owenshree & 34.5 & $\begin{array}{l}\text { Pasture (41.1) } \\
\text { Peat (27.9) }\end{array}$ & Pl (75.7) & 1501 & 530 & 971 \\
\hline Ballycahalan & 47.7 & $\begin{array}{l}\text { Forest }(37.5) \\
\text { Peat }(31.6)\end{array}$ & $\mathrm{Pl}(85)$ & 1501 & 530 & 971 \\
\hline Mattock & 11.6 & Pasture (84.6) & $\mathrm{Pl}(92.3)$ & 885 & 460 & 425 \\
\hline Nuenna (Rocky) & 21.6 & Pasture (83) & $\operatorname{Rkd}(84.2)$ & 1026 & 485 & 541 \\
\hline Nuenna (Monument) & 34.99 & Pasture (87) & Rkd (81.4) & 985 & 485 & 500 \\
\hline Glen Burn & 5 & Pasture (100) & $\mathrm{Pl}(100)$ & 843 & 460 & 383 \\
\hline
\end{tabular}

769 
Table 3. Recharge coefficients for different hydrogeological settings adapted from Hunter Williams et

\begin{tabular}{|c|c|c|c|c|c|}
\hline \multirow{3}{*}{$\begin{array}{l}\text { Vulnerability } \\
\text { category }\end{array}$} & \multirow{2}{*}{\multicolumn{2}{|c|}{ Hydrogeological setting }} & \multirow{2}{*}{\multicolumn{3}{|c|}{$\begin{array}{c}\text { Recharge coefficient } \\
\text { (RC) }\end{array}$}} \\
\hline & & & & & \\
\hline & & & $\begin{array}{l}\operatorname{Min} \\
(\%)\end{array}$ & $\begin{array}{l}\text { Inner } \\
\text { Range }\end{array}$ & $\begin{array}{l}\operatorname{Max} \\
(\%)\end{array}$ \\
\hline \multirow[t]{7}{*}{ Extreme } & 1.i & Areas where rock is at ground surface & 30 & $80-90$ & 100 \\
\hline & 1.ii & Sand/gravel overlain by 'well drained' soil & 50 & 90 & 100 \\
\hline & 1.iii & Sand/gravel overlain by 'poorly drained' (gley) soil & 15 & $35-50$ & 70 \\
\hline & 1.iv & Till overlain by 'well drained' soil & 45 & $50-70$ & 80 \\
\hline & $1 . v$ & Till overlain by 'poorly drained' (gley) soil & 5 & $15-30$ & 50 \\
\hline & 1.vi & $\begin{array}{l}\text { Sand/ gravel aquifer where the water table is } \leq 3 \mathrm{~m} \\
\text { below surface }\end{array}$ & 50 & $80-90$ & 100 \\
\hline & 1.vii & Peat & 1 & $15-30$ & 50 \\
\hline \multirow[t]{8}{*}{ High } & $2 . \mathrm{i}$ & Sand/gravel aquifer, overlain by 'well drained' soil & 50 & $80-90$ & 100 \\
\hline & 2.ii & $\begin{array}{l}\text { High permeability subsoil (sand/gravel) overlain by } \\
\text { 'well drained' soil }\end{array}$ & 50 & $80-90$ & 100 \\
\hline & 2.iii & $\begin{array}{l}\text { High permeability subsoil (sand/gravel) overlain by } \\
\text { 'poorly drained' soil }\end{array}$ & 15 & $35-50$ & 70 \\
\hline & 2.iv & $\begin{array}{l}\text { Sand/gravel aquifer, overlain by 'poorly drained' } \\
\text { soil }\end{array}$ & 15 & $35-50$ & 70 \\
\hline & $2 . \mathrm{v}$ & $\begin{array}{l}\text { Moderate permeability subsoil overlain by 'well } \\
\text { drained' soil }\end{array}$ & 35 & $50-70$ & 80 \\
\hline & 2.vi & $\begin{array}{l}\text { Moderate permeability subsoil overlain by 'poorly } \\
\text { drained' (gley) soil }\end{array}$ & 10 & $15-30$ & 50 \\
\hline & 2.vii & Low permeability subsoil & 1 & $20-30$ & 40 \\
\hline & ... & Peat & 1 & $5-15$ & 20 \\
\hline & $3 . \mathrm{i}$ & $\begin{array}{l}\text { Moderate permeability subsoil and overlain by } \\
\text { 'well drained' soil }\end{array}$ & 35 & $50-70$ & 80 \\
\hline & 3.ii & $\begin{array}{l}\text { Moderate permeability subsoil and overlain by } \\
\text { 'poorly drained' (gley) soil }\end{array}$ & 10 & $15-30$ & 50 \\
\hline & 3.iii & Low permeability subsoil & 1 & $10-20$ & 30 \\
\hline & 3.iv & Peat & 1 & $3-5$ & 10 \\
\hline \multirow[t]{2}{*}{ Low } & 4.i & Low permeability subsoil & 1 & $5-10$ & 20 \\
\hline & 4.ii & Basin peat & 1 & $3-5$ & 10 \\
\hline \multirow[t]{5}{*}{ High to Low } & $5 . \mathrm{i}$ & High predicted permeability subsoils (Sand/gravels) & 30 & $80-90$ & 100 \\
\hline & 5.ii & $\begin{array}{l}\text { Moderate permeability subsoil overlain by well } \\
\text { drained soils }\end{array}$ & 35 & $50-70$ & 80 \\
\hline & 5.iii & $\begin{array}{l}\text { Moderate permeability subsoils overlain by poorly } \\
\text { drained soils }\end{array}$ & 10 & $15-30$ & 50 \\
\hline & 5.iv & Low permeability subsoil & 1 & $5-10$ & 20 \\
\hline & $5 . \mathrm{v}$ & Peat & 1 & 5 & 20 \\
\hline
\end{tabular}


774 Table 4. Master Recession Curve analysis with flow apportioned to each pathway.

775

\begin{tabular}{|c|c|c|c|c|c|}
\hline \multirow[t]{3}{*}{ Catchment } & \multirow[t]{2}{*}{ Area } & \multicolumn{4}{|c|}{ Master Recession Curve, Tabulation Method } \\
\hline & & $\frac{\text { Groundwater }}{\underline{\text { Shallow }}}$ & $\frac{\text { Groundwater }}{\text { Deep }}$ & $\underline{\text { Interflow }}$ & $\underline{\text { Overlandflow }}$ \\
\hline & $\mathbf{k m}^{2}$ & & & & \\
\hline Deel & 283.1 & 0.296 & 0.114 & 0.148 & 0.442 \\
\hline Blackwater (Kells) & 699 & 0.117 & 0.148 & 0.477 & 0.258 \\
\hline Fyanstown & 187.6 & 0.192 & 0.037 & 0.1 & 0.671 \\
\hline Owenshree & 34.5 & \multicolumn{2}{|c|}{0.196} & 0.148 & 0.142 \\
\hline Ballycahalan & 47.7 & \multicolumn{2}{|c|}{0.212} & 0.333 & 0.455 \\
\hline Glen Burn & 5 & 0.117 & 0.104 & 0.437 & 0.341 \\
\hline Mattock & 11.6 & 0.147 & 0.073 & 0.254 & 0.526 \\
\hline Nuenna (Rocky) & 21.6 & 0.563 & 0.319 & 0.1 & 0.018 \\
\hline Nuenna (Monument) & 34.99 & 0.441 & 0.357 & 0.141 & 0.06 \\
\hline
\end{tabular}

776 
777 Table 5. Boughton and Eckhardt BFI and parameter values.

\begin{tabular}{|c|c|c|c|c|c|c|}
\hline \multirow[t]{3}{*}{ Catchment } & \multirow[t]{2}{*}{ Area } & \multicolumn{5}{|c|}{ Calculated BFI } \\
\hline & & $\underset{\text { (parameter) }}{\underline{\mathrm{K}}}$ & $\frac{\underline{\mathrm{C}}}{\text { (parameter) }}$ & $\frac{\text { Boughton }}{\text { (Calculated BFI) }}$ & $\underline{\text { (parameter) }}_{\text {BFax }_{\text {max }}}$ & $\frac{\text { Eckhardt }}{\text { (calculated BFI) }}$ \\
\hline & $\mathbf{k m}^{2}$ & & & & & \\
\hline Deel & 283.1 & 0.983 & 0.022 & 0.559 & 0.56 & 0.561 \\
\hline Blackwater (Kells) & 699 & 0.964 & 0.012 & 0.25 & 0.25 & 0.251 \\
\hline Fyanstown & 187.6 & 0.979 & 0.006 & 0.222 & 0.22 & 0.22 \\
\hline Owenshree & 34.5 & 0.997 & 0.004 & 0.141 & 0,14 & 0.14 \\
\hline Ballycahalan & 47.7 & 0.995 & 0.001 & 0.166 & 0.166 & 0.165 \\
\hline Glen Burn & 5 & 0.98 & 0.0032 & 0.14 & 0.14 & 0.142 \\
\hline Mattock & 11.6 & 0.991 & 0.0025 & 0.218 & 0.22 & 0.221 \\
\hline Nuenna (Rocky) & 21.6 & 0.999 & 0.006 & 0.859 & 0.86 & 0.86 \\
\hline Nuenna (Monument) & 34.99 & 0.999 & 0.005 & 0.835 & 0.835 & 0.837 \\
\hline
\end{tabular}


Table 6. NAM pathway separations.

\begin{tabular}{|c|c|c|c|c|c|c|}
\hline \multirow[t]{3}{*}{ Catchment } & \multirow[t]{2}{*}{ Area } & \multicolumn{5}{|c|}{ NAM } \\
\hline & & $\frac{\text { Groundwater }}{\underline{\text { Shallow }}}$ & $\frac{\text { Groundwater }}{\text { Deep }}$ & Interflow & Overlandflow & $\underline{\mathrm{R}^{2}}$ \\
\hline & $\mathbf{k m}^{2}$ & & & & & \\
\hline Deel & 283.1 & 0.383 & 0.199 & 0.104 & 0.315 & 0.921 \\
\hline Blackwater (Kells) & 699 & 0.124 & 0.046 & 0.227 & 0.604 & 0.921 \\
\hline Fyanstown & 187.6 & 0.244 & 0.056 & 0.18 & 0.52 & 0.803 \\
\hline Owenshree & 34.5 & \multicolumn{2}{|c|}{0.136} & 0.427 & 0.437 & 0.846 \\
\hline Ballycahalan & 47.7 & \multicolumn{2}{|c|}{0.071} & 0.246 & 0.683 & 0.90 \\
\hline Glen Burn & 5 & 0.049 & 0.078 & 0.436 & 0.437 & 0.89 \\
\hline Mattock & 11.6 & 0.148 & 0.106 & 0.496 & 0.25 & 0.848 \\
\hline Nuenna (Rocky) & 21.6 & 0.473 & 0.37 & 0.003 & 0.154 & 0.958 \\
\hline Nuenna (Monument) & 34.99 & 0.472 & 0.405 & 0.006 & 0.116 & 0.95 \\
\hline
\end{tabular}

782 
783 Table 7. Summary of BFI values using different approaches. 


\begin{tabular}{|c|c|c|c|c|c|c|c|c|c|c|}
\hline \multirow[t]{3}{*}{ Catchment } & \multirow[t]{2}{*}{ Area } & \multicolumn{9}{|c|}{ Calculated BFI } \\
\hline & & $\begin{array}{c}\underline{\text { Fixed }} \\
\text { Interval }\end{array}$ & $\begin{array}{l}\text { Sliding } \\
\text { Interval }\end{array}$ & $\begin{array}{c}\frac{\text { Local }}{\underline{\text { Minima }}} \\
\underline{\text { (N computed })}\end{array}$ & 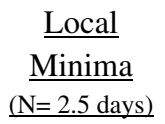 & $\frac{\mathrm{MRC}}{\underline{\mathrm{Tab}}}$ & $\frac{\text { Recharge }}{\text { Coeffs }}$ & Boughton & $\underline{\text { Eckhardt }}$ & $\underline{N A M}$ \\
\hline & $\mathbf{k m}^{2}$ & & & & & & & & & \\
\hline Deel & 283.1 & 0.871 & 0.871 & 0.668 & 0.668 & 0.559 & 0.415 & 0.575 & 0.57 & 0.582 \\
\hline $\begin{array}{l}\text { Blackwater } \\
\text { (Kells) }\end{array}$ & 699 & 0.775 & 0.807 & 0.517 & 0.542 & 0.25 & 0.204 & 0.25 & 0.251 & 0.17 \\
\hline Fyanstown & 187.6 & 0.667 & 0.697 & 0.527 & 0.542 & 0.222 & 0.253 & 0.222 & 0.22 & 0.253 \\
\hline Owenshree & 34.5 & 0.558 & 0.561 & 0.334 & 0.244 & 0.141 & 0.145 & 0.141 & 0.141 & 0.136 \\
\hline Ballycahalan & 47.7 & 0.812 & 0.795 & 0.764 & 0.757 & 0.166 & 0.167 & 0.166 & 0.165 & 0.071 \\
\hline Glen Burn & 5 & 0.556 & 0.55 & 0.344 & 0.284 & 0.221 & 0.189 & 0.14 & 0.142 & 0.127 \\
\hline Mattock & 11.6 & 0.582 & 0.582 & 0.522 & 0.249 & 0.218 & 0.351 & 0.218 & 0.23 & 0.254 \\
\hline Nuenna (Rocky) & 21.6 & 0.923 & 0.924 & 0.595 & 0.78 & 0.859 & 0.543 & 0.803 & 0.802 & 0.843 \\
\hline $\begin{array}{l}\text { Nuenna } \\
\text { (Monument) }\end{array}$ & 34.99 & 0.892 & 0.893 & 0.389 & 30 & 0.835 & 0.439 & 0.779 & 0.835 & 0.877 \\
\hline
\end{tabular}


786 Table 8. Response of calculated BFI using varying parameters in Eckhardt algorithm.

787

788

\begin{tabular}{|cccccc|}
\hline \multicolumn{7}{|c|}{ Eckhardt BFI } \\
$\underline{\text { Nuenna (Monument) }}$ & \multicolumn{1}{c}{} & $\underline{\text { Glen Burn }}$ & \\
$\underline{\mathrm{K}}$ & $\underline{\mathrm{BFI}_{\max }}$ & $\underline{\mathrm{BFI}}$ & $\underline{\mathrm{k}}$ & $\underline{\underline{\mathrm{FI}}_{\max }}$ & $\underline{\mathrm{BFI}}$ \\
0.9990 & 0.9000 & 0.901149 & 0.9990 & 0.9000 & 0.904 \\
0.9250 & 0.1000 & 0.100237 & 0.9250 & 0.1000 & 0.101 \\
0.9250 & 0.9000 & 0.900017 & 0.9250 & 0.9000 & 0.9 \\
0.6000 & 0.1000 & 0.100045 & 0.6000 & 0.1000 & 0.1 \\
0.6000 & 0.9000 & 0.900004 & 0.6000 & 0.9000 & 0.9 \\
0.1000 & 0.9000 & 0.900002 & 0.1000 & 0.9000 & 0.9 \\
0.9250 & 0.0020 & 0.002274 & 0.9250 & 0.0020 & .0026 \\
\hline
\end{tabular}



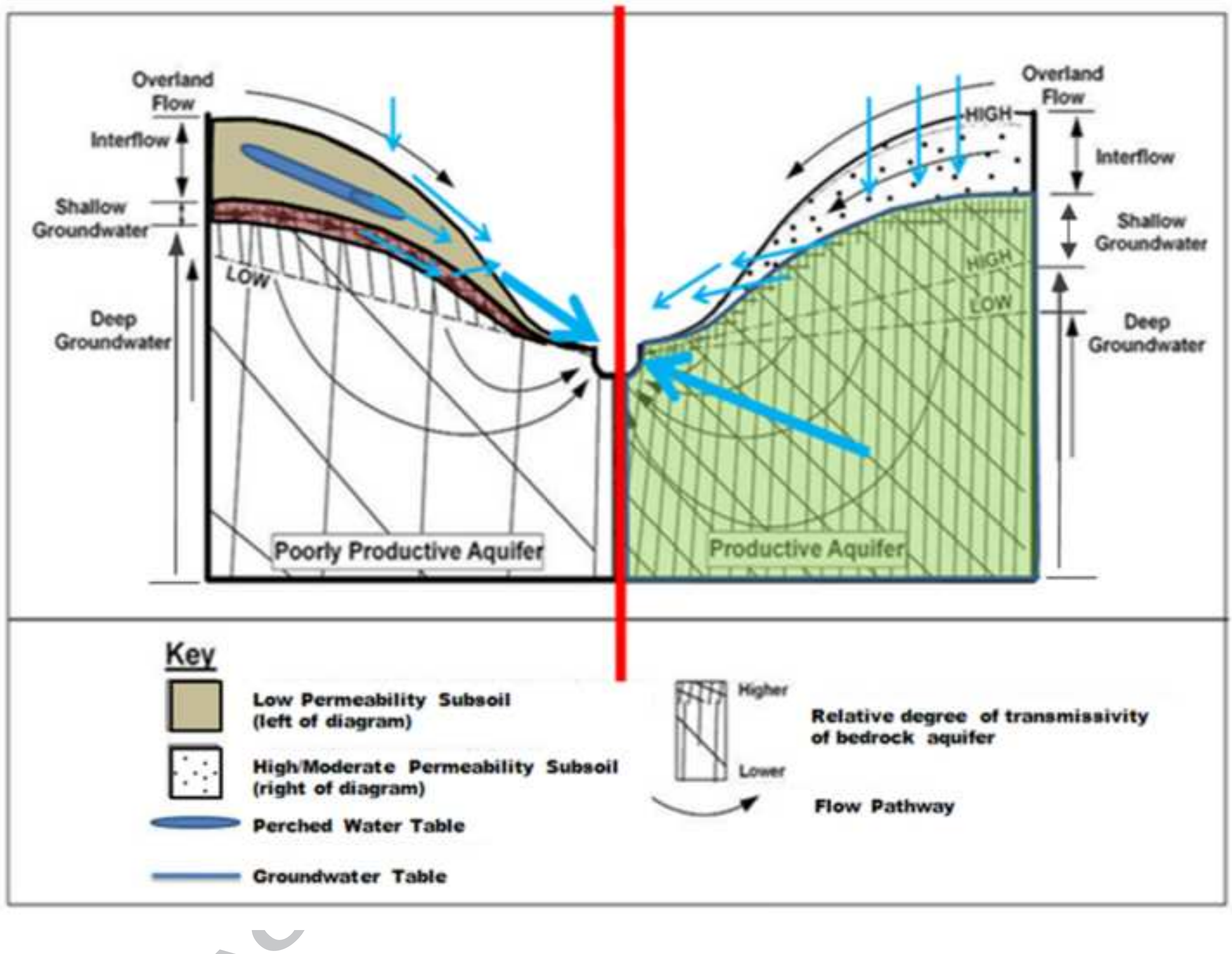


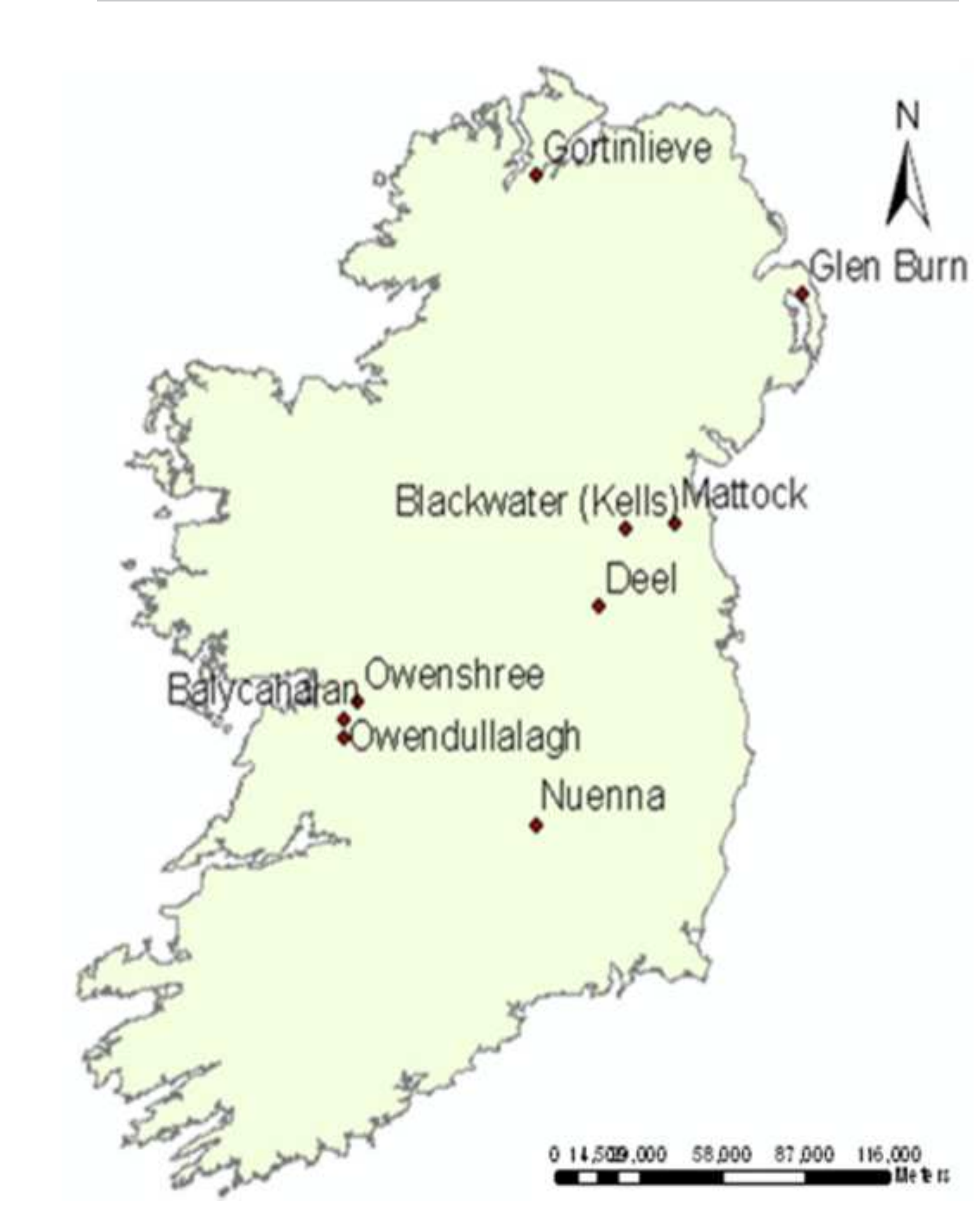

Figure 2 Study Catchment Locations

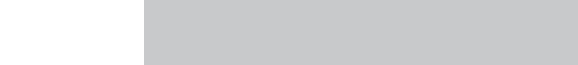

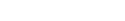




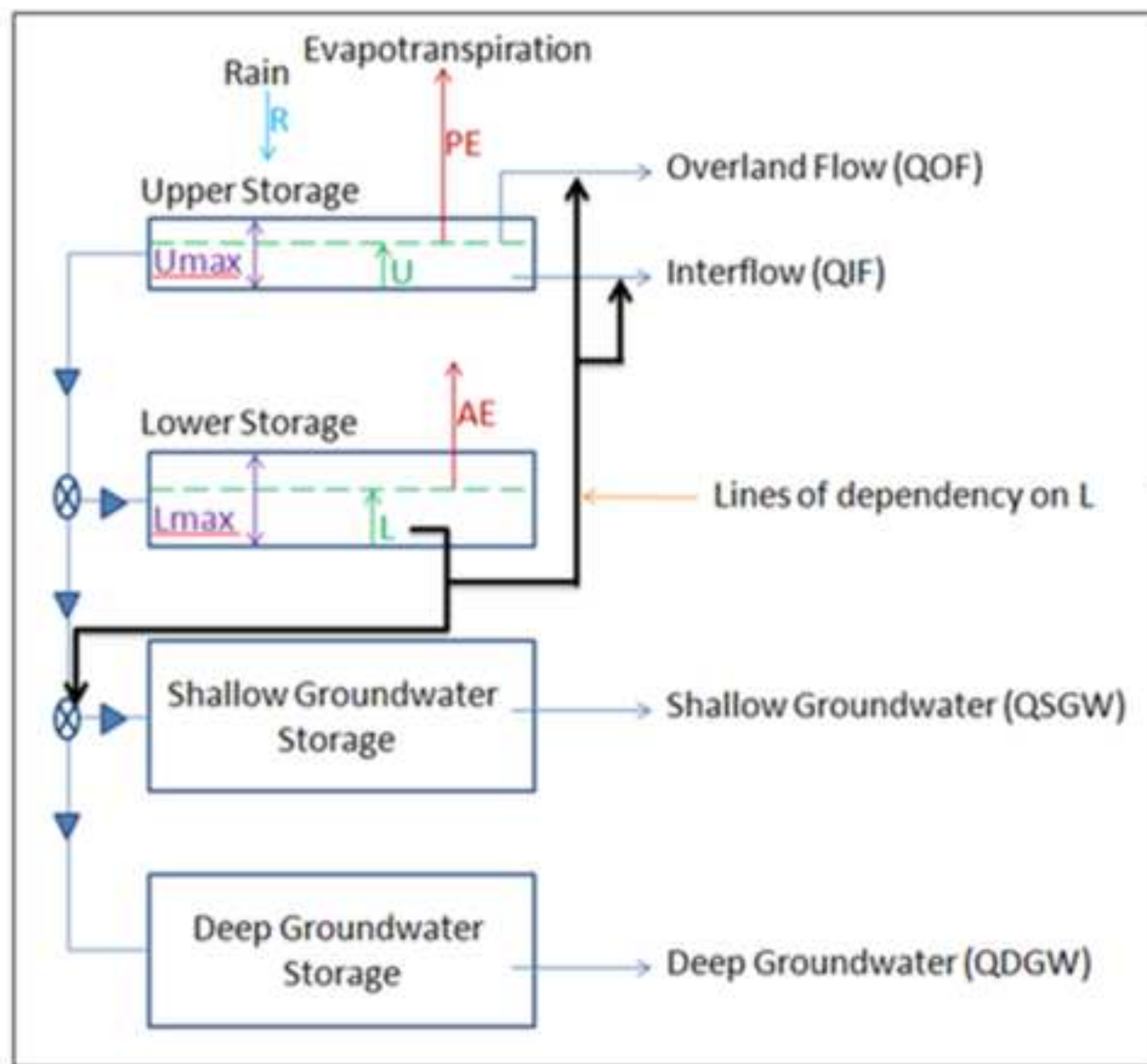

\section{Legend}

$\mathrm{R}=$ Rainfall ( $\mathrm{mm})$

$\mathrm{PE}=$ Potential

Evapotranspiration ( $\mathrm{mm}$ )

$\mathrm{AE}=$ Actual

Evapotranspiration ( $\mathrm{mm}$ )

$\mathrm{L}=$ Lower Storage $(\mathrm{mm})$

$\mathrm{U}=$ Upper Storage ( $\mathrm{mm})$ 


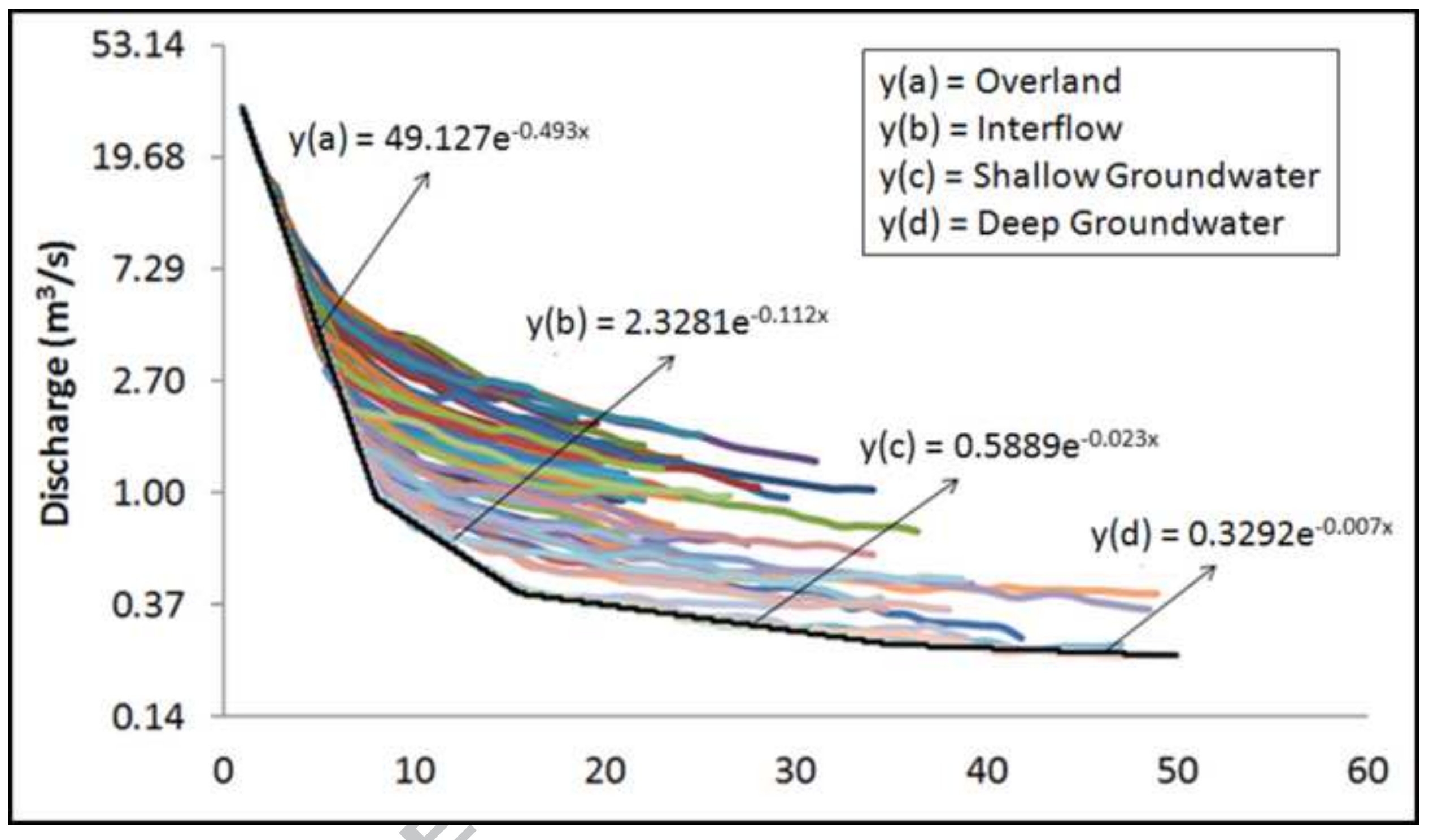

$y(a)=$ Overland

$y(b)=$ interflow

= Shallow

$y(d)=$ Deep Groundwater

$$
y(d)=0.3292 e^{-0.007 x}
$$
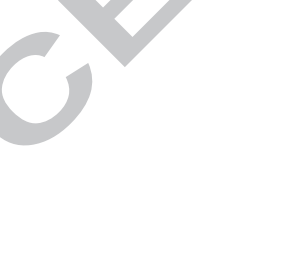


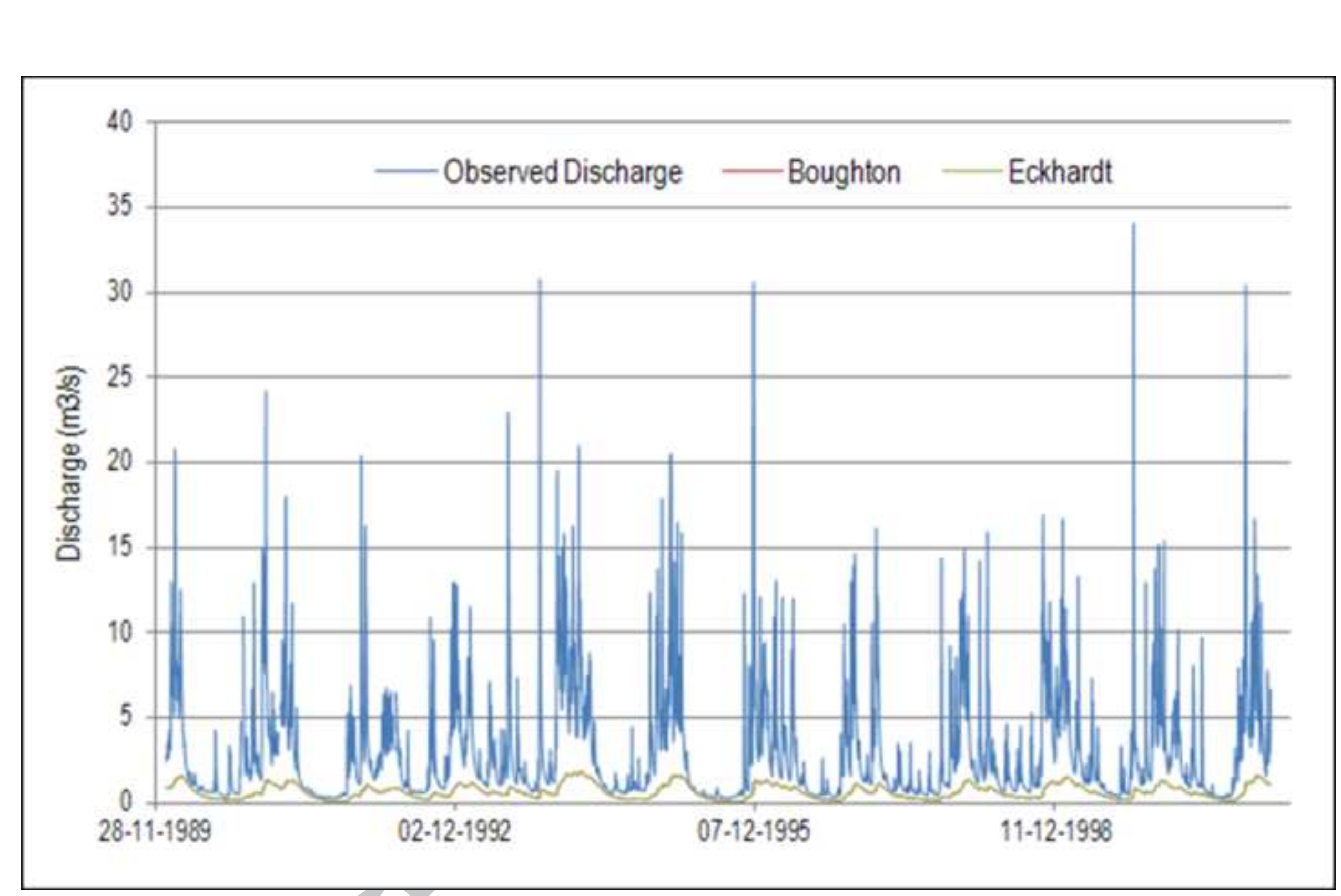

\section{ACCEPTED MANUSCRIPT
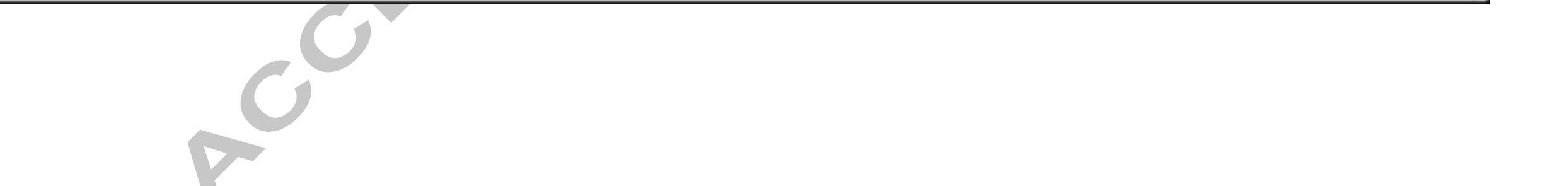


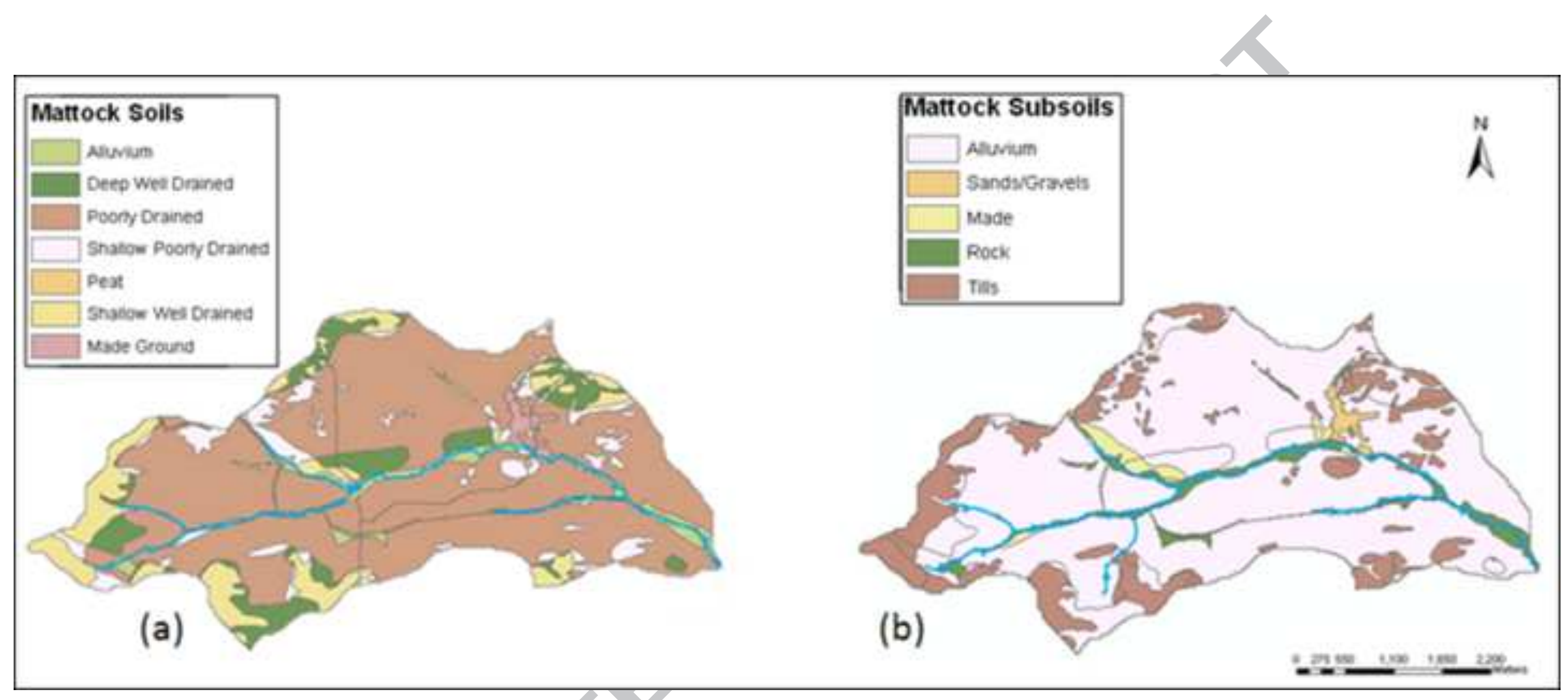

(a)

(b)

$-7=200$ 


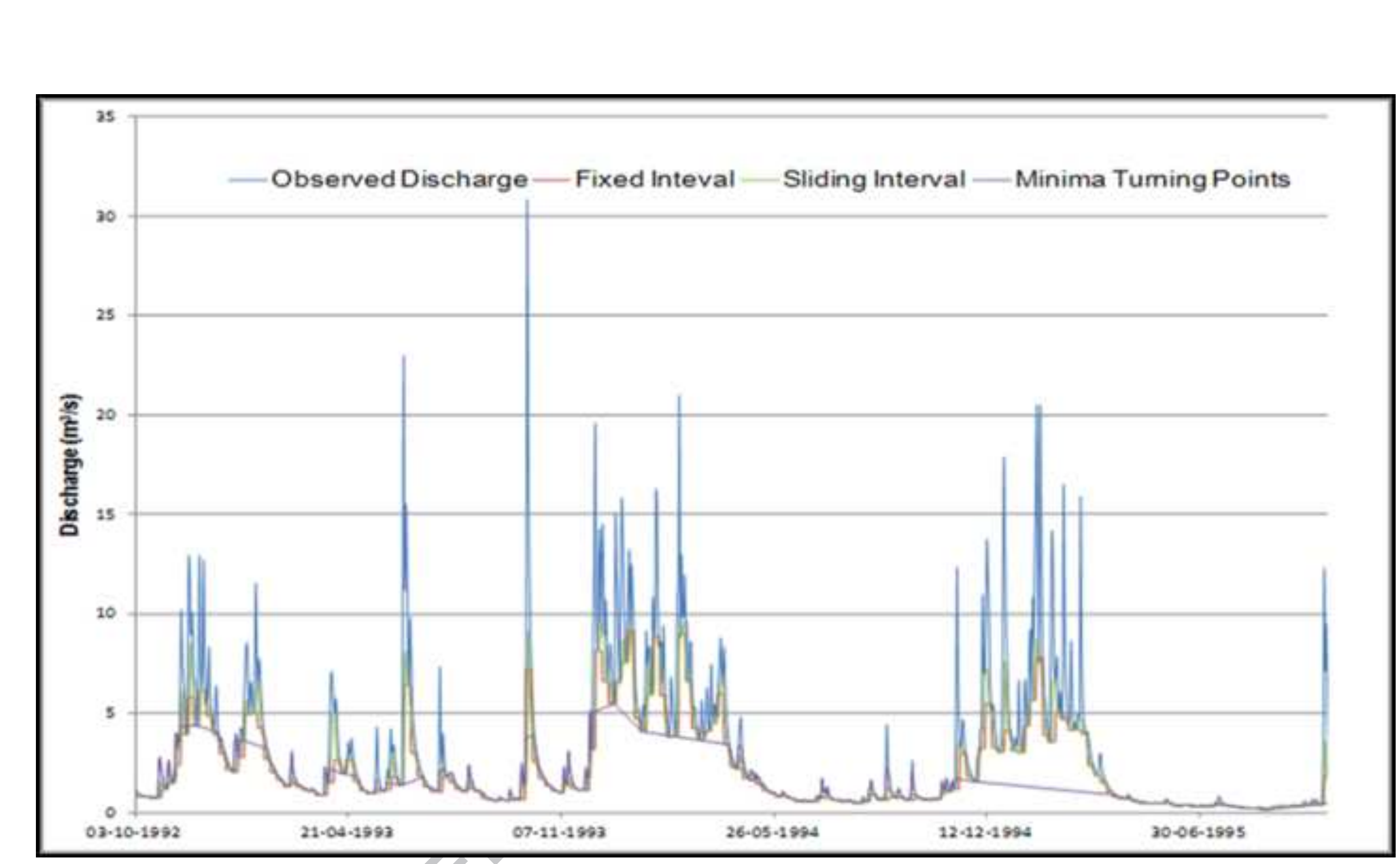 \\ ACOEPTHO MANUSCRIPT}



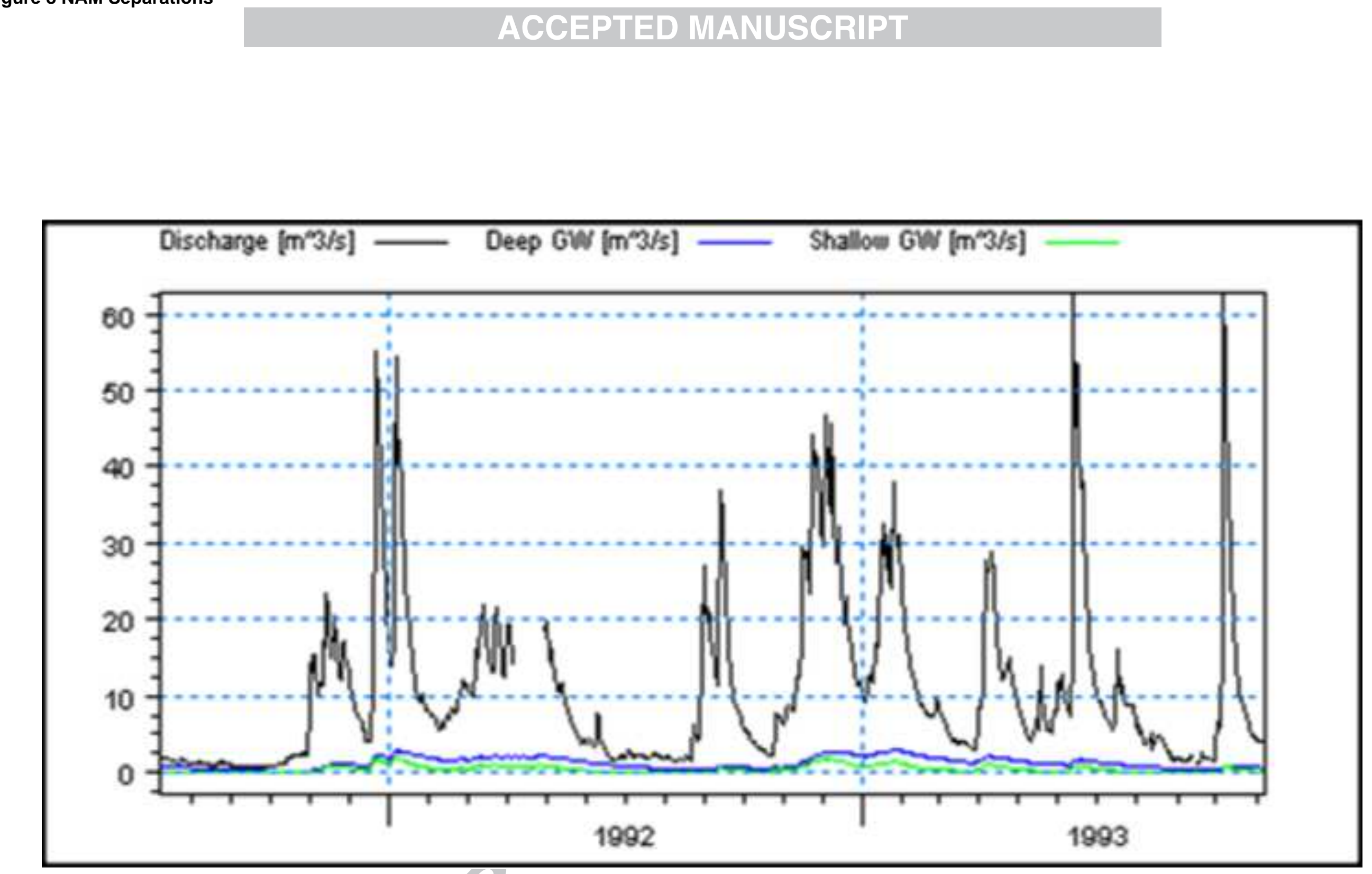
Highlights

790

- Outline of novel and objective approach to calculating Base Flow

791 Index (BFI).

792

- Reliable and repeatable method that can be applied to various

793 geological settings.

794

- Novel application of Master Recession Curve analysis with NAM

795 lumped model.

796

- Use of recharge coefficient method, developed in Ireland, to constrain

797 BFI values.

798 